Original Research Paper

\title{
The Boko Haram Terrorism: Causes Still Misunderstood
}

\author{
Sogo Angel Olofinbiyi and Jean Steyn \\ Department of Criminology, University of Kwazulu-Natal, Durban, South Africa
}

Article history

Received: 16-12-2017

Revised: 08-03-2018

Accepted: $30-03-2018$

Corresponding Author: Sogo Angel Olofinbiyi Department of Criminology, University of Kwazulu-Natal, Durban, South Africa Email: sogoukzn@gmail.com

\begin{abstract}
There have been widespread assumptions across the globe that the root cause of Boko Haram terrorism in Nigeria is religious rather than socio-economic. An investigation into this dichotomy allowed this study to fully demonstrate that the root cause of Boko Haram's terrorist actions emanates from the non-fulfilment of socio-economic goals that are prompted by the violation of fundamental human rights, corruption, poverty, unconstitutional and undemocratic practices in the northern part of the Nigerian state. To achieve its aim of establishing the root cause of the terrorism crisis in the latter country, the study critically appraised the socioeconomic context of the insurgency by adopting one-on-one in-depth interviews involving forty (40) participants to interrogate the phenomenon. Empirical evidence from the study demonstrated that the evolution of Boko Haram terrorism was a response to socio-economic phlebotomy, political and moral putrescence and the dehumanization of people that stem from a combination of decades of mismanagement and pervasive corruption by various Nigerian leaders. The study concludes that, as long as the endemic socio-economic problems caused by global capitalism vis-a-vis unequal hegemonic power exchange as expressed in socio-political, ethno-religious and cultural forms persist in the Nigerian society, the terrorism insurgency will recur and remain an inevitable enterprise and indeed a normal social reaction to every undesirable state of affairs. Based on the findings, the study urges the need for the amelioration of the conditions of the vast majority of the Nigerian populace by making socio-economic facilities available to them through the political state.
\end{abstract}

Keywords: Boko Haram Terrorism, Insurgency, Socio-Economic, Religious Injunctions

\section{Introduction}

Boko Haram terrorism, regardless of the lens through which it is viewed, is adjudged to be one of the greatest threats that humanity faces in recent Nigeria. Therefore, the causes of this phenomenon remain a controversial debate among citizens globally. One of the prominent assumptions of the behaviourist school of thought is the notion that the root causes of terrorism, war and violence are entrenched in human nature, human want and human behaviour and this creates a significant relationship between intra-personal conflict and conflict that pervades the external social order, such as the phenomenon that is manifested in Boko Haram terrorism in Nigeria (Eneanya, 2015). Boko Haram terrorism could be described as the by-products of unresolved conflict and the incapacity of the government or authorities concerned to submerge these challenges. The reflection that the root causes of such conflicts are not completely identifiable and that appropriate strategies to resolve or manage the scourge are elusive, was what gave impetus to this current study. Scholars have, at different times, propounded various theoretical models to explain the causes and prevalence of terrorism in human society. In this process, scholarly attempts to search for a peaceful and stable society have led to the emergence of various predominant theories to explain the trend of intrastate violence and social insecurity, namely Frustrationaggression and Relative deprivation (Dollard et al., 1939; Gurr, 1970; 2000; Eneanya, 2015), State failure (Rotberg 2002; 2003; Zartman, 1995), State failure and Frustrationaggression (Maiangwa et al., 2016) Resource curse (Bannon and Collier, 2003; Collier and Hoefller, 2004), Liability shift and Cognitive dissonance (Cunningham, 2003), Poverty-breed-conflict hypothesis (Awojobi, 2014), Psycho-cultural perspectives (Faleti, 2006) and 
Social learning theory and social identity (Eneanya, 2015). It has also been argued that neither of these theories lays adequate emphasis on unequal hegemonic power exchange as expressed in socio-economic, political, ethno-religious and cultural forms, which all form the basis for the experience of a failed state which, in turn, breeds poverty and the exacerbation of poverty across the civil society. It is within this context that frustration may arise to ignite a class conflict that will eventually engender high levels of violence in society.

Most recent studies on the Boko Haram problematique have not adequately addressed the cause and effect sequence of the sectarian phenomenon. In effect, there appears to be little or no conscious attempts to understand the socio-economic basis of the crisis and its humanitarian effects on national security in Nigeria. On the contrary, many people have channeled their respective opinions towards religious injunctions, particularly Islam, as the most viable context for the existence of the Boko Haram insurgency in Nigeria. Therefore, this research sought to fill this gap in the literature in order to add to the extant knowledge on the subject matter. It is also expected that the study will make valuable policy recommendations on how to reposition the fight against terrorism in Nigeria in order to eradicate this scourge.

More importantly, the widespread assumptions about the cause of Boko Haram terrorism in Nigeria have made it difficult for many researchers, particularly those that have shown a high sense of research interest, to have a clear-cut understanding of the root cause of the crisis. The study was therefore fundamental in establishing the major cause of the Boko Haram impasse in the country in order to nip in the bud all the hypothetical statements surrounding the cause of the problem. The study will therefore illuminate the direction that should be taken to tackle the menace in order to restore peace, stability and orderliness among the affected Nigerian communities.

\section{Research Methods}

A good research design was adopted for the study. The adoption of the research design provided an opportunity to formulate strategies that examined the topic under investigation and specified the most appropriate procedures employed for gathering the richest possible data for the research. The study employed an indepth semi-structured one-on-one interviews to interrogate the phenomenon of Boko Haram terrorism in Nigeria. In executing this methodological approach, participants for the interviews were selected as key informants. This was necessary to facilitate the collection of rich data as the participants could be probed beyond the capacity of questionnaires. This minimized possible errors of interpretation and enhanced the trustworthiness of the research as high-quality data could be collected to the point of saturation. A significant justification for selecting a qualitative research design was motivated by a desire to move beyond the inadequacy of close-ended approach of questionnaires and possible errors that are usually generated by the dominant quantitative approach based on a positivist paradigm.

\section{Study Population and Sample Size}

The study population covered two different categories of stakeholders with their age bracket ranging from the penal age of 18 and above. These were:

1) Government Officials:

a. Security Operatives (specifically officers in the Police Force, the Nigerian Army, State Security Service (SSS), Prison and Customs)

b. Political office holders

2) Civil Society Organizations:

a. Business men and women

b. Students from tertiary institutions

c. Religious leaders (both Christianity and Islam)

d. Abuja Metro Police Community Relation Committee members from within the area council

Gender equality was also considered within the study population to avoid confining the entire study to a particular sex. Although this study was not a comparative gender study of participants, the study deemed it important to establish an approximate gender balance in the sample. On this account, 40 participants comprising 12 female and 28 male individuals were sampled for the study.

Of the total of 40 participants, 5 informants were selected as representatives of each stakeholder group in order to allow for a more comparative research study. The technique for determining the sample size for the study was based on a tentative judgement considering the pragmatic and redundancy criteria which could, to a large extent, influence the choice of the qualitative sample. As a general rule of thumb, qualitative samples for a single study involving individual interviews often lie under 50 (Ritchie and Lewis, 2014). On this basis, 40 participants were sampled for the study. This selection technique was observed to moderate the interviews against becoming too difficult and complex to manage in terms of the quality of the data that were collected and analysed.

\section{Sampling Techniques}

Sampling as it relates to social research is the selection of individuals, categories, specimens, units and/or settings to be studied (Hagan, 2006). In any research study, the sample is a small part of the whole or population from which information, facts or ideas about the whole are generated. Therefore, a small population of the participants was selected from the larger population of Abuja residents. 
Table 1: Tabular Presentation of participants sampled for the study

\begin{tabular}{lr}
\hline Stakeholders & Number sampled for an interview \\
\hline Security operatives (Police officer, army officer, SSS, prison officer, customs officer) & 5 \\
Political office holders & 5 \\
Islamic leaders & 5 \\
Christian leaders & 5 \\
Business representatives (male) & 5 \\
Business representatives (female) & 5 \\
Students & 5 \\
Abuja metro police community relation committee representatives & 5 \\
Total number of participants sampled & 40 \\
\hline
\end{tabular}

A purposive sampling technique was utilized to select participants for the interviews. This selection method was based on motive, the key criterion and relevance of the respondents to the theme of the study. In the purposive sampling approach, the selection of participants, settings or other sampling units is criterion-based or purposive (Mason, 2002; Patton, 2002). It is stressed that "the sample units are chosen because they have particular features or characteristics which will enable a detailed exploration and understanding of the central themes and questions which the researcher wishes to study" (Bryman, 2012). Sometimes these characteristics may be sociodemographic or they may relate to specific experiences, behaviours or roles. Some even label this approach as "judgement sampling" (Hagan, 2006).

The recruitment of participants for the research took place from a pool of government officials and civil society organizations, thus forming two categories of stakeholders for the study. Five representatives of various designations were purposively selected as key informants from a pool of security operatives and political office holders in Nigeria. Five leader representatives from the Islamic and five from the Christian religions were also selected for the study by purposive sampling. Five representatives were purposively selected from businesses comprising both male and female, five representatives from students of tertiary institutions and five members of the Abuja Metro Police Community Relation Committee in the area council were also selected. Table 1 presents a tabular presentation of the participants for clarification.

\section{Method of Data Collection}

The fieldwork for the study was conducted between January and July in 2017 in Abuja (Federal Capital Territory and the North-Central region of Nigeria). Qualitative data were collected by in-depth interview method during semi-structured interviews. All the information was recorded on audio tape with the approval of the participants. This process was also supplemented with the use of field diaries in which various salient points were recorded during the interviews. The latter process was deemed vital and useful for validating the outcomes of the research inquiry.
At the end of each day of interviews, the principal researcher reviewed and edited the recorded interviews and field diaries to check for voice frequency, internal consistency, accurate recording, completeness, screening and other related issues. The interviews were recorded and transcribed and those statements that had been expressed in local languages were translated into English by a competent translator. Each interview session lasted about one hour.

As stated earlier, semi-structured interviews utilizing lead questions were conducted to collect data for the study. This process employed the use of an audio recorder and field notes to validate the data that were obtained and processed. The interview guide was structured in such a way that adequate information was elicited to address the research questions and objectives of the study

This selection technique and the compilation of the sample facilitated a comparative research approach as each representative sample group offered their opinions on the subject under investigation from a particular vantage point. This selection technique was highly appropriate as it was able to subside the redundancy effects associated with qualitative data collection of a larger scope. The process of data collection reached saturation point when sufficient credible and dependable data had been collected and when no further new insights could be provided by the participants. It is also reiterated that participants for the in-depth interviews were drawn from all six the district areas of the Abuja local council in Nigeria. This process ensured that the data that were generated from the interviews represented a comprehensive picture that addressed the research questions and the findings thus supported the objective of the study. Because the current study did not utilize a cross-sectional survey method, a series of interviews was conducted in the study location with key informants in order to balance the large body of empirical data that might have been obtained from a questionnaire survey approach.

\section{Negotiating Access for the Recruitment of the Participants}

Negotiating access for the recruitment of participants was a crucial step in the research design of this study. 
Blaxter et al. (1997) note that one of the factors that determine a successful research study is the researcher's consideration of how to obtain approval from the institutions or individuals that govern a research setting. The consent of the institutions concerned with this research study was sought and formal approval was obtained in writing (i.e., a gatekeeper letter) to conduct the research. The starting point for the preparation of the fieldwork commenced with the approval of this research by authorities of the selected institutions. The next step was to obtain ethical clearance approval from the higher degree committee of the School of Applied Human Sciences at the University of KwaZulu-Natal. Thereafter, the researcher proceeded to undertake the fieldwork. This enabled the researcher to proceed to the different sites where the research participants were located. Thus accessing and recruiting participants on arrival in the field where the primary data collection phase of the research would be conducted were enabled.

\section{Method of Data Analysis: Qualitative Analytical Method}

In carrying out a successful research inquiry, the collected data need to be analyzed efficiently to elicit valid and trustworthy findings. Because the data that were generated in the study were solely qualitative, a process referred to as 'thematic content analysis' was utilized to analyze and explain the data that had been compacted into manageable chunks. Content analysis is a qualitative methodological approach that is defined as "a systemic, replicable technique of compressing many words of text into fewer content categories based on explicit rules of coding (Krippendorff, 1980: 1-84; Weber, 1990). "This is a technique for making inferences by systematically and objectively identifying specified characteristics of messages" (See Oyefara, 2011:105). In this process, the recordings and notes of the in-depth interviews were transcribed from English or a local language (i.e., Yoruba, Hausa, Nupe, Gwari, Igbo or Pidgin) to English text. The responses to each question were summarized and important quotations were reported verbatim for the sake of authenticity and to validate the findings of the study. It should be noted that content analysis was done manually in order to enhance the explanatory clarity of the findings. It is also paramount to note that the data analysis followed a set of five stages to ensure adequate and comprehensive analyses. With reference to Ritchie and Spencer (1994), these steps were as follows:

\section{Familiarization}

This entails the reading and re-reading of the transcripts, research notes and their translation to ensure data reduction. The audio recordings of the interviews were transcribed verbatim. Thereafter, the transcripts were reviewed and typed to provide raw data for analysis. This process enabled the researcher to identify key words that formed key themes and ideas as they began to emerge from the initial readings of the transcripts.

\section{Identification of Themes}

This process concerned the notification and identification of major themes. The themes were identified from key words or ideas in the data and were in turn used to examine the data. As new themes emerged during the interviews, they were added and examined in relation to the research questions. This process was followed by an open coding procedure which was utilized for the identification of all emerging themes that were deemed relevant to address the research questions.

\section{Coding and Indexing}

During this stage, the researcher applied data that emerged from the thematic framework elicited from the data. Each section of the text garnered form the interviews was marked with appropriate themes and coded with particular numbers or short phrases. This stage dealt with the identification of all emerging themes that were deemed relevant for an in-depth understanding of the data.

\section{Charting}

The data were re-arranged under main headings and sub-headings according to the themes that had been identified. All the statements belonging to a specific theme were arranged into a single file using Microsoft Word Excel. This was used to distinguish or note the similarities that existed in the opinions of the different stakeholders selected for the interviews.

Mapping and Interpretation: This was the final stage of the data analysis process. The range of responses, central themes and shared perceptions as well as dissenting viewpoints were condensed and interpreted. Significant quotes expressing the emerging themes were noted and highlighted. Finally, the outcome of the study relies on participants' in-depth data information, comparative analysis of findings with previous research inquiries in related studies. This enhanced the credibility and dependability of the research through a thick and rich description of participants' understanding of the patterns that maintain the Boko Haram terrorism in Nigeria.

\section{Findings and Discussion}

\section{Socio-Economic Versus Religious Perceptions of Boko Haram Terrorism}

There have been widespread assumptions across the globe that the root cause of Boko Haram terrorism in Nigeria is religious rather than socio-economic. 
However, the data obtained in this study debunked this perception, as it was comprehensively demonstrated that the evolution of Boko Haram terrorism was nothing but a response to socio-economic phlebotomy, political and moral putrescence as well as dehumanization born from a combination of decades of mismanagement and pervasive corruption by Nigerian leaders. The study found evidence to argue that the root cause of Boko Haram terrorism is the non-fulfilment of socio-economic goals emanating from the violation of fundamental human rights, corruption, poverty and poor and unconstitutional democratic practices in the northern part of the Nigerian state. This argument is seemingly aligned with Njoku's (2011) postulation that the root causes of terrorism in the third world cannot be divorced from poverty, which is an end-product of the evil effects of globalization facilitated by the Bretton Woods industrialized capitalist states, leading to the expression of hatred through violent attacks on government institutions, both foreign and local. In support of the above argument, a prisons officer stated the following:

"To me, Boko Haram has its origin from economic crises in north-eastern Nigeria. In an interview with a Boko Haram commander in Kuje prison, he saw himself as a transformed man, which he ascribed to an Islamic team that came to preach the true Islam to them. When asked during the interview where does Qur'an justify killing of people and civilians, the commander repeatedly said he could not remember. It is like he doesn't want to explore that old frame of mind of their ideology of false Islam. He said and I quote: 'I've changed. I don't want to talk about justification now. But I have come to realize now that we have been manipulated and the centrality of our fight and ideology is baseless'. When questioned on what he perceived the root cause of their violence against Nigeria was, he said: "I don't know but I just joined the group because of my poor condition. I don't know when they started their crisis but because of my keen activeness on the battlefield, I was made a commander. As for the cause of the crisis, we used to hear Shekau say when addressing the camp, 'Our people are suffering under the rulership of political hypocrites... We must not relent! No retreat, no surrender. Our people must be freed from poverty and hardships. If our weapons fail us, we will fight with our souls.."

To buttress the above information, an Army officer, a businessman and a Christian religious leader contributed the following:
The Army officer stated:

"As earlier said, Boko Haram crisis has
many facets associated with socio-economic
conditions of people... Severe corruption in
the Borno state government could be seen
as the root cause of Boko Haram
insurgency in Nigeria."

The business man declared:

\begin{abstract}
"Corruption of the northern political chiefs is a factor. They want to divert the attention of the masses from their inability to run the economy of the country efficiently and effectively, thereby enabling them to embezzle more money....It is not a religious issue at all. Islam! Hawusubillai!"
\end{abstract}

A Christian religious leader offered the following insight:

"No! to be honest, I don't think the Islamic religion has anything to do with Boko Haram terrorism...but it is only unfortunate that the group originated from a Muslim youth movement organization... That is why so many people believe they are Muslims and that they are fighting to Islamize the country....To me it is a socio-economic and political crisis caused by bad leadership in north-eastern Nigeria."

To complement the above argument, a businesswomen stressed the following:

"Boko Haram terrorism is caused by the way our leaders are squandering our resources and it does not cut across all the citizens. People are suffering and Boko Haram members believe that education made them to be self-centred and corrupt."

Taking a comparative look at the above data, one may conclude that socio-economic factors are more viable for understanding the root causes of Boko Haram terrorism than religion. More specifically, a wide margin between the religious and socio-economic contexts of the argument is created which debunks several findings that blame the root cause of Boko Haram terrorism on Islamic injunctions.

This finding seems to resolve the intricacies behind the misconception that religion and specifically the Islamic faith, is the root cause of Boko Haram terrorism in Nigeria. An examination of the empirical data 
suggests that the Islamic religion is relatively minor among the factors that pioneered and sustain the Boko Haram crisis in Nigeria. Carefully unfolding this finding, it appears that although the sect may portray a particular kind of background affiliation to the Islamic religion probably by speaking the language of Islam and making references to the Qur'an in the course of executing their activities - one thing that is clear is that Islam is merely harnessed by this terrorist sect as a platform from which its members vent their anger and grievances of the global community. Evidence of this assertion is supported by the statement of a prisons officer:

\begin{abstract}
"They are not Muslims, but frustrated northerners. Interviews with some of the BH inmates in Kuje prison confirmed that these people are not Muslims because the majority of them are illiterate and can't even cite the Qur'an, yet they say they are doing 'jihad'. Few of them are learned... they have read the Qur'an and the Hadith, but they don't really understand Islam. I guess they are controlled by the devil. Interviews with them also show that Boko Haram terrorists are mostly men with little formal education, with hand-tomouth jobs on the urban margins...they are people commonly looked down upon even by Muslims in their own community as 'riff-raff". They are angry because of their miserable lives and religion is the platform to express that anger... I can describe them as frustrated beings hiding under religion to perpetrate evils."
\end{abstract}

A statement by an officer in the State Security Service corroborated this:

"Based on the information given to the State Security Service in line with our investigation, as you know we live on information. The cause of Boko Haram has much to do with economic crises in north-eastern Nigeria, aided by corrupt political leaders. We guess the political leaders initiated this insurgency by making use of the group for selfish political interests, after which they are now trying to curb it. Unfortunately, it is no more within their control. It is completely a political crisis, not a religious issue. They may be using Islam to reach out their grievances to the world. But if these people were truly Muslims, they would not be attacking fellow Muslims and Islamic communities.

On being probed further, this participant stated:

\begin{abstract}
"Do you know the cause of the split of Boko Haram in 2016 during which Al-barnawi was appointed over Shekau as the new leader by the Islamic States? It is because Shekau attacked fellow Muslims in Chad-Niger regions and in Nigeria. Even ISIS terrorist organization frowns at Boko Haram attacking Muslim fellows. This is strong evidence to prove that Boko Haram terrorists are not Muslims... or they may be backslided Muslims. Take that from me!"
\end{abstract}

According to some scholars and researchers such as (Adesoji 2010; Pham, 2012; Cook, 2011; Olagunju, 2012; Agbiboa, 2013e; Idahosa, 2015), Boko Haram terrorism in Nigeria is a product of an attempt by some northern states' leaders to rule and Islamize the entire country. To Idahosa (2015), the primary motive behind Boko Haram's deadly insurgency in the north-east of Nigeria for the last six years has been to enshrine Sharia laws as state laws. According to Olagunju (2012:10), it seems that the Boko Haram fundamentalists frown on Western education and, for this reason, many thought they were really illiterates. It has indeed come to light that although some are poorly educated, not all Boko Haram members are illiterate, but that they are embarking on an ideological war to accomplish a set of stated goals. However, the findings of this study also disagreed with those of (Adesoji, 2010; Pham, 2012; Cook, 2011; Olagunju, 2012; Agbiboa, 2013; Idahosa, 2015) by demonstrating that the targets of Boko Haram are Christians, Muslims and innocent Nigerian citizens regardless of their religious denomination. This assertion renders the position of the listed authors inadequate in their respective attempts to fully explain the Islamic fundamentalism of Boko Haram terrorism within the Nigerian context.

Addressing the root cause of Boko Haram terrorism in Nigeria, an officer in the Nigerian Army offered the following opinion:

"Walahi, the cause is more socio-economic and political issues in north-eastern Nigeria, not Islam. Because if we look at the beginning of the crisis, it all started from north-eastern Nigeria where many people are living in abject poverty. The truth is that the northern political leaders are not doing fine; they are too corrupt and they deprive most of their citizens of their fundamental rights to socioeconomic opportunities such as jobs, sound education, good health facilities, food availability and anything that humans need to make a life. Any opinion that Islam is the cause is far from reasonable thoughts." 
On being probed, he also stated:

\begin{abstract}
"However, we all know that Boko Haram was formally an Islamic organization originating from this region - Borno - by Yusuf. We all heard of the good will of the organization in the early 2000s when they were making provisions for the needs of the citizens, helping government to perform their responsibility before they eventually accused government of severe acts of corruption and maltreatment of eligible Borno citizens. Now, their acts of killing Muslims and bombing mosques have proved them not to be Muslims any more. We have to realize this!"
\end{abstract}

A 72-year-old Islamic cleric, a business woman and an undergraduate student of a tertiary institution offered the following insights in answer to the same question. The cleric stated:

\begin{abstract}
"Hmmm! What I think is that some political hoodlums have hijacked the group name as a tool of extorting and disrupting the government under the disguise of Boko Haram. The cause is not religious but I can say it is from corruption of the political leaders. They deny so many people, especially in that north-eastern Nigeria of their rights to live in good standard as against the Islamic teachings of Prophet Mohammed. Maybe the frustrations and agony of poverty in the region led to this crisis today. But I know the group has been influenced by some wicked and powerful leaders. My son, with my deeper understanding of Islam and time-long reading of the Holy Book, I want you to know that there is nowhere in the Qur'an that says you should have to kill for God."
\end{abstract}

A successful business woman was of the following opinion regarding the root cause of Boko Haram terrorism in Nigeria:

"Initially they were being used as political thugs and sponsored by politicians and when their leader failed election, they vowed to disorganize the country and the tenure of the new government. In my own opinion, there is nothing tangible they are fighting for other than to make trouble and meet ends needs through terrorism.... Well, if I will be sincere with you, Boko Haram is caused by a political problem, not Islamic as many people think...It is just unfortunate that these people have a background history with Islam. "
An undergraduate student stated:

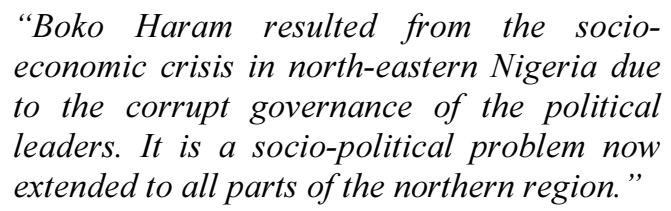

An analysis of the data strongly propels the notion that the widespread assumption that the root cause and rising insurgency of Boko Haram terrorism in Nigeria occur as the religious injunctions of Islam is not only misleading, but erroneous based on the findings. In the view of a cleric, true Muslim believers will never harm their fellow believers, yet members of the sect had been witnessed killing fellow Muslims as well as attacking religious institutions such as mosques and other Islamic centres. Ninalowo (2011: 152) argues along the same direction, stating that no religious tenet anywhere in the world condones violence or termination of human life or destruction of life and property. He argues further that the best explanation for terrorism must be attributed to the existential factors of the human condition. On this note, this study suggests that the unequal hegemonic power configuration between the northern political state and civil society vis-a-vis the non-fulfilment of socioeconomic needs as expressed in socio-political, ethnoreligious and cultural forms may be more viable in promoting a lucid understanding of the root cause of Boko Haram terrorism in Nigeria.

From the vantage of the social exchange theory, this study conceived Boko Haram terrorism as an attendant consequence of unequal exchange resorting to possibilities of resistance and challenge against the northern sovereign authority. When putting together different scholarly ideas about the social exchange process and what it stands for as a binding force that draws human society together, chiefly when the exchange is equal on both sides, one can see that the theory argues that satisfaction and peace will exist when people receive fair returns for their expenditures, but that fundamental conflicts of interest are generated when people receive the bad side of the exchange. This theory is reflected in the situation between the northern political state and its citizens, where Boko Haram terrorists wage a war for a fairer deal. As an interjection, it may be argued that although their motives may find sympathy in many quarters, their tactics are deemed repulsive by observers and victims alike. Secondary data that were reviewed revealed that the living conditions in northeastern Nigeria have been worsened by a minority of leaders in the region who cause a sizeable number of northern citizens to live in abject poverty, unemployment, hopelessness, backwardness, diverse recession, frustration, social dislocation, misery and underdevelopment. Therefore, the accrued nonfulfilment of socio-economic goals resulting from 
unequal exchange between the northern political state and the frustrated citizens is conceived to have led not only to the emergence of Boko Haram terrorism in Nigeria, but also to its sustainability. This argument was validated during the interview with a 65 -year-old Christian leader:

"The Boko Haram fight has nothing to do with religion. The origin was more socioeconomic and political in northern Nigeria where severe corruption and slavery of the poor masses exists. It is a legitimacy crisis...Boko Haram is just revolting against the government of the northern states, but the fight has gone out of hand now."

Looking critically into the above data, the social conflict perspective supports the understanding that the Boko Haram insurgency is an elongation and attendant consequence of an unequal exchange between Nigeria's political state and the poor masses. It is in this context that members of the Boko Haram sect seem to have emerged with a view to revolting against northern leaders through forms of violence and radicalism that have escalated to illicit disruptions of the existing political states and the brutalization and termination of lives and property in the northern part of Nigeria. This study found credible evidence to buttress the findings submitted by Adibe (2012) who asserts that the frustration of the poor masses, precipitated by factors such as severe poverty, unemployment and elite corruption, generates fundamental conflicts of interest within the affected masses who constantly feel oppressed, alienated, deprived, frustrated and abandoned. The study also radiates a great deal of symmetry with those of Kwaja (2009:1; Schwartz et al., 2009:540; Omede, 2011:93), who similarly argue that "the religious dimension of the Boko Haram conflict has been misconstrued as the primary driver of the violence when, in effect, disenfranchisement, ineffective governance and structural inequality are assumed to be the root causes of the phenomenon". For Mustapha (2012), Boko Haram could be best described as the symptom of the failure of nationbuilding and democratic politics in Nigeria. His argument that "the misguided cry of the disgruntled youth, crushed by the socio-economic system, is more viable than religion in any attempt to establish the root cause of Boko Haram terrorism in Nigeria" has thus been corroborated by the current study.

The current research inquiry also found evidence to debunk Wole Soyinka's, submission that Boko Haram is the handiwork of "disgruntled northern Muslim politicians who desire to make life unbearable for a southern Christian president (cited in Agbiboa, 2013). However, the study agrees with Bintube (2015), who argues that socio-economic factors are the major influences responsible for the Boko Haram insurgency in Nigeria. Bintube's assertion, coupled with the assertions in his section, validates the findings of this study in terms of the root cause of Boko Haram terrorism.

Based on the comparative research approach adopted for the analysis and discussions of findings of this research and sharp comparisons with previous research inquiries, the study concludes that socio-economic factors are the key variables accountable for the emergence and maintenance of Boko Haram insurgency in Nigeria. In support it presents a broad range of factors such as poverty, joblessness, illiteracy, false religious doctrines, economic deprivation, state-actor terrorism, bad governance occasioned with leadership deficits and failures, non-fulfilment of the social contract with regard to the provision of basic amenities to the citizenry by the political state, corruption, greed, political deceit and injustice as the springboard for Boko Haram terrorism in Nigeria.

\section{The Religious Misconceptions of Boko Haram Terrorism}

The Islamic fundamentalism of Boko Haram terrorists has made an appreciable number of people across the globe believe that the terrorists are fundamentally Muslims. It is this researcher's contention that one of the most important findings of this study is that this perception was refuted by the data. Scholars, politicians, economists and ordinary citizens reportedly believe that that religious fervour is the cause of Boko Haram terrorism and that Boko Haram terrorists are Muslims whose activities are in accordance with the will of God as stated in the holy Qur'an. However, an empirical finding of this study, supported by a statement by Ninalowo (2011), state unequivocally that there is no religious tenet anywhere in the world that condones the illicit and wanton termination of lives and destruction of property. The fact that Boko Haram terrorists were seen on the streets of northern communities where they killed fellow Muslims and set mosques and other Islamic centres ablaze is sufficient evidence to argue that these militants are not Muslims in the true sense of the word and that they could therefore not be waging a 'holy' war based on Muslim teachings. The study discovered that these people might have a kind of background affiliation to the Islamic religion rather than to any other religious denomination, because on most occasions they speak the language of Islam and accord their atrocities to the will of Allah in statements and video clips. The leadership thus seems to deliberately create the highest level of confusion about Islam as a religion that upholds violence, radicalization, the termination of human life and the destruction of property. Their volatile situation has also given birth to a religious segregation and, in 
some instances, ill-will between Christian and Muslim associations in Nigeria, whereas the constitution is clear on the nation's right to freedom of religious association. In light of this finding, the researcher contends that until the Nigerian society is able to re-examine its religious conceptions based on this particular finding of this study, relationships among the Nigerian population will continue to exude suspicion and people will experience daily threats due to religious misconceptions. Sadly, until such a time, many religious believers, both Christian and Muslim, will wallow in the doldrums of ignorance caused by false religious teachings. Empirical evidence that generated this finding was expressed in the statements of many of the participants. Some are highlighted below.

A community police member stated:

$$
\begin{aligned}
& \text { "Another more prominent effect includes } \\
& \text { religious segregation and racial } \\
& \text { discrimination as people now see anybody } \\
& \text { coming from the north or Muslim population } \\
& \text { as Boko Haram." }
\end{aligned}
$$

Being further probed, he continued:

\begin{abstract}
"Whatever cause/reason they may be fighting for should not warrant killing fellow human beings. Besides, they are political instruments who advanced to become Boko Haram. Never think they are Muslims, they are not according to Islamic doctrines. That is why I said the other time that by the time they turned terrorists, they are no more Muslims. But the fact that they speak the language of Islam has confused a lot of people making them believe they are Muslims. I must tell you the pioneers and founding fathers of Boko Haram cannot control them any longer because they have turned to a mad dog in their hands."
\end{abstract}

A 67-year-old Christian offered the following insight:

\begin{abstract}
"We [originally] thought their intention was to reduce the Christian population by their Islamic state declaration, but when they now started to attack their fellow Muslims and Islamic centres, we got confused and with this we began to doubt if they are truly Muslims. As for the cause of the problem, I don't really think it is an Islamic crisis, as it is more political."
\end{abstract}

A 72-year-old Islamic leader contributed the following:

"If I won't be biased, Boko Haram are Muslims, but they are not good Muslims!
Because I don't think any religion in the world could condone the killing of fellow human beings."

An officer in the Nigeria Police Force opined as follows:

"I don't know who they are except that they showcase their ideology to be of the Muslim faith. They preach Islam and demonstrate Islamism each time I listen to their leader, Shekau, on video tapes. But I don't believe they are Muslims. Initially I thought they were Muslims but with their mode of operations and activities, it shows clearly that they are not Islamic faithfuls. We have seen them kill Muslims, destroy Islamic centres and kill people regardless of their religious denomination. In fact, nobody can say actually anything about their religion. But it is unfortunate that they hide under Islam to do evil. Nobody can say they are Christians as they have nothing to do with Christianity since they began their evils in Nigeria. To me, they are neither Christians nor Muslims. They have their own ideology which has nothing to do with Islam that they claim they are."

An officer in the Nigerian prison service shared the following:

"They are not Muslims but frustrated
northerners. Interviews with some of the Boko
Haram inmates in Kuje prison confirmed that
these people are not Muslims because the
majority of them are illiterate and can't even
cite the Qur'an, yet they say they are doing
'jihad'. Few of them are learned. They have
read the Qur'an and the Hadith, but they
don't really understand Islam. I guess they
are controlled by the devil. Interviews with
them also show that Boko Haram terrorists
are mostly men with little formal education,
with hand-to-mouth jobs on the urban
margins. They are people commonly looked
down upon even by Muslims in their own
community as 'riff-raff'. They are angry
because of their miserable lives and religion is
the platform to express that anger. I can
describe them as frustrated beings hiding under
religion to perpetrate evil deeds."

When the data were compared and analyzed, it was revealed that Boko Haram terrorists have a specific ethno-religious link with Islamism but that this does not suggest that these terrorists adhere to the Muslims 
faith and that the spate of their terrorist activities in Nigeria has its root in Islamic doctrines as laid down by Prophet Mohammed.

\section{Conclusion}

The study thus engaged in an extensive and in-depth research inquiry to unravel the intricacies surrounding the phenomenon of Boko Haram terrorism in Nigeria. It dwelled on theoretical reflections of the social exchange and conflict theories to bring to the fore a better understanding of the socio-economic variables that produce, reproduce and sustain the crisis in Nigeria. The outcome of the research confirms Boko Haram terrorism as a political crisis that stems from the failure of the Nigerian state to make socio-economic facilities available to all eligible and law-abiding citizens of the northern states - an effect that is now keenly felt across a wide range of the Nigerian society, with an extension to neighbouring states' communities as well. The study found sufficient evidence to argue that religious extremism and the evolution of the Boko Haram sect into terrorism can be associated with the failure of the government to engage in a uniform and fair distribution of socio-economic resources to the northeastern citizens of the country.

It was found that numerous efforts had been made and were being made at the time of the study to alleviate the various problems associated with Boko Haram insurgency in Nigeria. However, these efforts have been largely ineffective in curbing terrorism in Nigeria; thus the suggestions made by this study to eradicate the problem will certainly leave the door wide open for further contributions by societies, governments and nongovernmental and international organizations to the discourse so that the effects of all efforts can be maximized in resolving the affliction of the communities that are affected by terrorism in Nigeria. In this context, the essential contribution of the study to the terrorism discourse in Nigeria is that the conception of a religious Islamic fervour as the root cause of Boko Haram terrorism has been debunked and that a paradigm shift in the counter-terrorism strategies to resolve the Boko Haram crisis in Nigeria is recommended.

The study projects that, as long as the pervasive socio-economic problems caused by unequal hegemonic power configuration as expressed in socio-political, ethno-religious and cultural forms persist in the Nigerian society, the insurgency by terrorists will recur and will be sustained as an inevitable enterprise and a social reaction to the unsatisfactory state of affairs in Nigeria. On the whole, whether military or peaceful negotiations resolve the problem or not and whether it is a religious, economic or political crisis, the study emphasizes the need for governments at various levels to put in place more effective life-changing programmes that will mitigate socio-economic hardships and prioritize satisfactory conditions of living for all law-abiding citizens. This will hopefully prevent the sustained perpetration of violence, terrorism and other crimerelated social vices that may persist in plaguing the peace of the Nigerian state.

\section{Policy Recommendations}

The study suggests the need to design and subsequently implement effective, pragmatic and curative policy recommendations as well as prevention and intervention programmes that will resolve the problem and prevent the future occurrence of similar phenomena in Nigeria. On the basis of the findings of this study, the following recommendations are offered.

\section{Provisions to Address Socio-Economic Needs}

Because the study has identified socio-economic problems as a primary cause of Boko Haram terrorism in Nigeria, governments at both national and local levels should ensure that socio-economic resources are uniformly distributed to the wider society. In this regard, the government of Nigeria is mandated to provide instrumentality towards the sustenance and amelioration of the human condition. This should chiefly occur through the provision of basic goods and services that will fulfil the needs of the citizens such as job opportunities, political recognition, formal education, housing, nutrition, health care facilities, clothing, an effective public transport system, internet facilities, communication and other resources needed to improve citizens' standard of living and quality of life. By the same token, local governments and democratic leaders should make information and basic services available to the citizens so that they can understand the adverse consequences of state of insecurity on their quality of life and on sustainable development. This will enable policy makers to design and adopt more appropriate policies and intervention strategies that will enhance the general well-being of the populace.

More importantly, government and NGOs should be sensitized towards making the special needs and concerns of common citizens a priority, as well as making socio-economic and political infrastructures available in all regions. This may safeguard moral rectitude and ensure effective individual and group contributions to national development. Because the study exposed prevailing corruption as the number one public enemy in Nigeria, there is a need for the government of Nigeria to establish strict legal measures at all levels against individuals who are caught in the act of corruption, with particular reference to the embezzlement of public funds to sponsor terrorism. This will help in preventing the sustainability of terrorism and other related offences in Nigeria. Also, due to pervasive corruption that seems to be embedded within the 
government system and which hinders the efficiency of the armed forces, the government should start looking at solutions from socio-economic and political angles rather than maintaining a military approach in its efforts to eradicate terrorism. This recommendation is premised on the fact the cause of the crisis was shown to have had its origin in socio-economic and political issues rather than in a particular religious ideology.

By taking such positive steps, terrorists and all terrorist sponsors will be dissuaded from taking undue advantage of human conditions to lure and recruit lawabiding citizens into their web of terrorism.

\section{Re-orientation of Political Values}

There should be a re-orientation of political values in among members of the Nigerian government and potential leaders. The ruling elite must re-orientate their mindset to accommodate political and ideological values to serve the people selflessly and magnanimously in accordance with the interests of the populace. There is an urgent need to change the perceptions of political office holders towards democratic dispensations, making them believe that the interests of civil society are paramount and should be taken into consideration in decisionmaking. They should always remember that democracy implies a government of the people by the people and for the people. In this regard, they should be made to realize that they occupy that political position by election and not by selection. Therefore, it is mandatory that they give back to their respective societies who elected them. In the broader context and based on lessons learnt in this study with reference to terrorist insurgency in neighbouring countries, politicians across the African continent should stop making politics a do-or-die affair or recruiting able-bodied youths as foot soldiers for political violence and radicalization. There is a need for people to stop being desperate for political positions with the ultimate intention of misappropriating public funds to the detriment of the poor masses. The fact that this study identified an African democratic government as a breeding ground for predisposing the youth towards terrorism demonstrates that there is an urgent need for African leaders, particularly in Nigeria, to adjust this aspect of their political culture that tends towards corruption, youth brainwashing, hooliganism, oppression and the dehumanization of the poor masses rather than serving their people through transparency and accountability.

\section{Accountability and Transparency Among Government Officials and Political Office Holders}

Transparency and accountability among political office holders is a good recipe for the reduction and prevention of corruption, oppression, radicalization, misappropriation of public funds and societal conflict that torment civil society. The principle of joining accountability and transparency should guide the activities of state functionaries, thereby making them answerable to the public and accepting accountability for their actions according to moral and ethical standards. This is what is referred to as 'accountability'.

Transparency is conceived as the process whereby government officials and political office holders are meticulously open and honest in the performance of their duties and functions. Conforming to the joint principle of transparency and accountability should help alleviate tendencies for widespread corruption among topmost civil servants and political office holders. However, government should make arrangement for appropriate incentives and motivations for officials as standard institutional practices. When the objectives of accountability and transparency of government functionaries are established across different government institutions, there is a high possibility of good governance and a uniform distribution of socio-economic resources which form the backbone of human existence. Hence there should also be a radical reduction in incidences of corruption and institutional conflict such as those that pioneered Boko Haram terrorism in north-eastern Nigeria.

\section{Youth Empowerment Programmes}

This has to do with the provision of equitable opportunities for young men and women who possess competence and abilities to enable them to participate in key aspects of life. Such empowerment programmes should incorporate decision-making strategies in political and economic aspects of social life, as well as the provision of vocational skills for able-bodied unemployed youths. The Federal Government of Nigeria should lift the embargo on employment and embark on a recruitment exercise for all categories of able-bodied youths who are willing to work, but who have remained unemployed through no fault of their own. If jobs are made available to millions of unemployed youths, it is hoped that there will be a radical decrease in their involvement in terrorism and extremism in Nigeria.

Many effective policies should be put in place to combat violence and terrorism in Nigeria. These include economic policies aimed at eliminating poverty and hunger, which are the springboard of Boko Haram terrorism in the country according to the findings of this study. Other policies should address youth welfare. A rehabilitation and health policy should also address the needs of youths that need rehabilitation should they be released from the clutches of the likes of the Boko Haram group and programs and support mechanisms should facilitate youths' full absorption into society as worthy citizens who will contribute to the sustainable development of the country in the future. 


\section{Collaborative Fight Against Corruption}

This study exposed corruption as the number one public enemy in Nigeria; its presence is pervasive and inimical to the progress of the Nigerian nation and sustains the Boko Haram crisis in the country. The government should therefore engage in collaborative efforts to fight corruption at all levels of government and to rid the Nigerian system of this menace. Strict legal measures should be taken against individuals (regardless of their socio-political status) who are caught engaging in any form of corrupt practices, who demonstrate an inordinate ambition to misappropriate public funds and who violate the fundamental human rights or moral code of behaviour in favour of a selfish agenda to the detriment of the poor masses. Achieving this goal will require state governments to strengthen and reform anticorruption agencies such as the Economic and Financial Crime Commission (EFCC) and the Independent Corrupt Practices Commission (ICPC). They should be compelled by regulations and regular evaluations to function more effectively in accordance with the motives upon which they were established. If corruption is totally wiped out of the Nigerian socio-political system, the possibility of people stealing public funds and government resources to facilitate and finance terrorism will be eradicated. More importantly, the study suggests that the important legacy of the Magna Carta of 1215 be enshrined, strengthened and enforced to function within the Nigerian social system so that everyone, including all leaders irrespective of socio-political status, should be made equal before the law. Implementing this timehonoured agreement will then serve as a renewed antidote to corruption, treasonable felony and the illicit violation of fundamental human rights across Nigeria and, eventually, across a broad range of African societies that may become inspired by the Nigerian success story of a true democracy.

\section{Enactment of Draconian Laws Against Terrorism and Terrorist Sponsors}

This study found that most terrorist activities are difficult to submerge because of their affiliation to some powerful group or groups of people and disreputable organizations in society who volunteer to sponsor them from their financial and information reservoirs. It is therefore unavoidable that, while a terrorist group has covert connections with its sponsors, terrorism will always be sustained and continue to eat deep into the social and economic fabric of a society. On this account, this study suggests that some draconian measures be enacted against anyone who is found guilty of, or who is even suspected of, sponsoring terrorism in Nigeria. Such measures may include the death sentence or life imprisonment; criminalizing the financing of terrorism across the six geo-political zones of Nigeria; and freezing without delay any funds or resources related to persons or organizations involved in acts of terrorism both at home and abroad. This will have to be done with the assistance of international organizations as the funds may be lodged in foreign accounts. All forms of financial support for terrorist groups should thus be blocked and withheld. This can best be achieved through governmental efforts, institutional initiatives, community engagement and cooperation, suppressing the provision of safe havens and blocking any sustenance support for terrorists. This can be facilitated through community policing and governmental efforts and the sharing of information regarding any terrorist group or groups that plan to engage in terrorist acts. Community policing, cooperating among government departments and with other governments in the investigation, detection, arrest, extradition and prosecution of those involved in such acts are practices that should be honed if terrorism is to be combated effectively. This can best be facilitated through community policing and governmental efforts. Taking such positive steps will discourage terrorism, terrorist sponsors and those who are still planning covertly to finance terrorism in order to achieve a number of selfish goals.

\section{Enforcement of the Rule of Law}

The government of Nigeria should engage in constitutional reform to ensure that everyone is equal before the law, irrespective of one's official position and social status in society. Therefore, anyone caught or suspected of encouraging terrorism should face the wrath of the law, regardless of the position he or she may be holding in society. More importantly, the supremacy and the enforcement of the rule of law must be adjudged sacrosanct and inviolable so as to ensure the sanctity of fundamental human rights and to mitigate against the possibility for fundamental conflicts of interest which may eventually engender the eruption of crises such as Boko Haram terrorism in Nigeria.

\section{A Peaceful Negotiation Approach}

The comprehensive findings of this study suggest undeniably that the Nigerian government should engage in a new epistemological shift in its approach to counterterrorism strategies. This implies that it should shift from the militarized, armed conflict approach to more culturally acceptable conflict resolution strategies in order to fight Boko Haram terrorism effectively. The study argues that more than half a decade of the 'fire-for-fire' approach towards the terrorist group has not produced any desired results. This pragmatically suggests that terrorism cannot always be fought by means of deploying conventional weapons alone. On this note, it is suggested that the Nigerian government should, at this crucial point, seek 
remedies of another dimension. One such remedy is the adoption of a diplomatic approach involving psychological and ideological strategies such as peaceful negotiations on equal terms in order to achieve success in the fight against the insurgents. Empirical evidence to showcase the efficacy of this approach is reiterated: "The two-week negotiations between the Nigerian government and Boko Haram-brokered by officials from the International Federation of the Red Cross and [the] Swiss government, among others-arguably led to the release of twenty-one of the Chibok girls on October 13, 2016 (Al Jazeera, 2016) and "...as the negotiations continued, another cohort of eighty-two Chibok girls was released on 7 May 2017" (Olofinbiyi, 2017)

Conversely, the findings related to the military approach suggest that, over seven years of violent struggle with the terrorist group, the armed forces have not achieved any noteworthy successes other than the death of some terrorist, who must have been quickly replaced by the recruitment of more young people as the data revealed that many youngsters have become quite willing to join the insurgents for food, clothing, weapons and safety. Therefore, a growing intensity of Boko Haram terrorism has been experienced in the traumatized regions. The advent of relatively successful negotiations (the reader should note that not all the girls were subsequently released) thus serves as a point of departure and hope for all nations that negotiate with extremist groups such as Boko Haram. In brief, it is submitted that a 'soft-handed' option could be a better option than a 'hard-handed' approach in resolving violent radicalization and terrorism.

\section{A Community Policing Approach}

This study identified a community policing approach as another practicable paradigm shift in the counterterrorism strategy. The study suggests that the Nigerian government should adopt this approach as a litmus test in resolving the Boko Haram problem should the negotiation strategy fail. The findings revealed that community policing holds a hidden secret as it is a powerful information channel which is a viable tool in criminal investigations. It therefore has high potential for achieving greater results in crime prevention, reduction and control than any other strategy. Based on this finding, the government should institutionalize and strengthen non-uniform community police forums across the northern region as an extended arm of the police force by, if possible, empowering them with a policing mandate but making them remain within their local communities where they can still have access to the information network that will help resolve crises and prevent the occurrence of any terrorist attacks that may pose a threat.

Secondly, the study urges the government to look into this approach and to engage intelligence officers both in the army and the police to discharge a collaborative plan with community police members to unearth authentic Boko Haram members and their supporters both at home and abroad. There is also an immediate need for government and civil society to stop undermining the efficiency of these people and to recognize their powerful role in crime reduction and control. It should be noted that these people have the potential to easily access and liaise with members of the local communities where Boko Haram operates. The study further suggests that the government should, even though negotiations are on-going, start looking in this direction as plan B in case the negotiation approach fails.

Thirdly, the government should strengthen community police forums across all states of the Federation by making them collaborate with the security forces. In this manner the military will be better prepared and informed as the community police will work with them as a powerful information weapon to augment the efforts of the military troops. The idea of community policing, if formally and officially incorporated into the security system of Nigeria, could eventually be one of the best approaches to prevent future occurrences of crime, terrorism and other related social vices that may disrupt the envisaged peaceful existence of the Nigerian populace. Though community police members are also human. However, potential for (for example) bribery, manipulation, intimidation and exploitation, which characterize the Nigerian system should be carefully addressed in achieving this goal.

\section{Youth Education, Orientation and Development}

Several studies have shown that education has a strong capacity to modify the behaviour of the youth either negatively or positively, depending on the quality of the information provided. Thus, education has a high potential for influencing the minds of the youth in a positive direction if appropriate information and incentives are provided. The study thus urges the governments of the federal states to incorporate a new module into the curriculum that should focus on terrorism and conflict studies. This should be enough to provide the youth with information on the social, emotional and psychological ills of terrorism on society and youth development. Based on the findings of the research, the lack of access to formal education as a factor that renders a sizeable number of northern youths vulnerable to Boko Haram brainwashing and recruitment is highlighted. Because education stands out as a major factor that influences behaviour, it can be used effectively to introduce behaviour modification in youths and in society as a whole. With improved education, various aspects of human life will be addressed, thereby facilitating a positive perception of people's worldview and a rise in the general living standards of society. To 
achieve this goal, government should sensitize northerners to the importance of education and contribute more to education in order to change the perspectives of northerners on Western education in order to prevent future occurrences of terrorism. Secondly, there is an urgent need to implement programmes that will cater for the conditions of illiterate youths in the northern states by making formal education available to them all. This programme could be initiated and tagged "Operation flushing out ignorance from the North" with the primary objective of sweeping away high incidences of illiteracy and ignorance caused by a lack of access to educational opportunities in the region. The study pays tribute to the formal education efforts of the Almajiris in the north, stressing that they should be trained and empowered with educational facilities and good jobs. The study also adds that daily spiritual discussions that will question the basis of the ideology of violence should be encouraged among the youth who are most susceptible to terrorist recruitment. With these strategies in place, the possibility of youths falling prey to terrorists' false religious teachings and recruitment should become issues of the past.

Finally, it is hoped that by taking these positive steps towards solving the various problems of the youths of the north in terms of their educational development, their potential for degenerating into terrorism as a means of compensating for their conditions of hopelessness, poverty and severe unemployment will be minimized. This could also result in a drastic reduction of the effects of terrorism on the region.

\section{Fortification of the Coercive Security Apparatuses of the State}

This study found that the Nigerian security forces, particularly the armed forces and the police, are weakened by a lack of modern and sophisticated weaponry and a digitalized infrastructure to ensure effective and efficient operations in their effort to protect and defend the territory against internal aggression. These lapses are reportedly owing to severe corruption in the administration of the military, which is a travesty from which the army chiefs are allegedly (and sadly) not exempt. This implies that there is an urgent need for the government to formulate and implement appropriate policies that will ensure the provision of modern technology and improved weaponry to allow the armed forces to discharge their duties more effectively. Until state governments can review their policies and eradicate corruption, the military will remain the inefficient puppets of a corrupt regime. If the military is placed in a position where it has access to better technology, informed intelligence and security administration systems to fight terrorism, it will achieve the desired results.
The engagement of United Nations forces may also be cardinal in resolving the problem of terrorism in Nigeria. For example, intelligence training of members of the armed forces and the procurement of military aircraft or much cheaper modern drones to monitor and track down Boko Haram hideouts should be considered. Achieving this would go a long way in strengthening the security network of the Nigerian Army.

There is also a need to strengthen the border security network by sanctioning armed forces to secure the borders using sophisticated apparatus so that all immigrants coming into the country can be properly checked by detectives and powerful computerized investigative tools.

Finally, for the military approach against Boko Haram terrorists to be more efficacious, government should abide by the code that what the Nigerian Army does is 'secret till the day of execution'. By adhering to this approach, the media must be compelled to refrain from announcing on radio and television what the armed forces' strategies and plans of action are. Training more security forces and the deployment of military troops to the Sambisa Forest are also imperative. If the suggested measures are taken into cognizance, the military will be afforded better opportunities to reposition their strategies for greater efficiency.

\section{Community Sensitization}

Designing awareness programmes about terrorism and the adverse effects of such acts and disseminating the information among communities are vital requirments, particularly in deep rural communities that are most vulnerable to attack. The level of awareness of the implications of terrorism should be heightened among the populace. There should be more enlightenment programmes by the government, international organizations such as the United Nations, the European Union, the African Union and NGOs. Such programmes should emphasize the extent to which terrorism can bring a nation and her future to ruin. The media, schools, churches, mosques, market centres and relevant associations should be actively involved in this campaign. Portable electronic devices such as cellular phones, tablets and I-pads that are fast and reliable means of disseminating information across the country should be encouraged in creating awareness about terrorism and its perilous effects on sustainable development. This also implies infrastructural upgrading to ensure that these devices function optimally.

\section{Rehabilitation of and Care for Terrorist Abductees}

A programme that involves the provision of psychological and emotional support to individuals who were abducted and set free by terrorists is vital. Based on the conceptual and theoretical argument of the 
differential association theory, this study suggests that there is a high possibility that these people were indoctrinated due to the long-term interaction that they shared with the insurgents. It is noteworthy that anyone who has been abducted by a terrorist group is like a time-bomb that can explode at any time. Therefore, state governments should not take their well-being after their release for granted, but they should put rehabilitation programmes in place that will constantly examine and re-examine the psychological and mental conditions of these people, particularly the released Chibok girls. Special attention should be given to these girls because there is a high probability that some may sympathize with their abductors and thus with further acts of terrorism if no adequate psycho-medical help is rendered to them. These efforts should continue from time to time until they are confirmed medically and mentally stable from the depression they suffer from, after which they can be fully reintegrated into society.

\section{Discouraging the usurpation of power and authority}

The illicit abuse of power and authority by government officials, political office holders and security operatives should be strictly discouraged and monitored. The study established that the undue abuse of power and authority is among the factors that usually pioneer nonstate terrorism which led to the emergence and contributes to the escalation of Boko Haram terrorism in Nigeria. There is therefore an urgent need to re-orientate all government officials, be it politicians or security operatives, to stop inflicting wickedness and unfair treatment on citizens. This will go a long way in establishing a good working relationship between security operatives and citizens, as well as averting any impending conflicts that may arise between the citizens and the political state.

\section{Provision of Pre-Emptive Safety Measures}

Pre-emptive safety measures that involve the use of modern technology should be placed at strategic points on the streets of each city to record any untoward activities. Safety measures such as emergency call boxes, cameras, emergency notification systems (phone, emails and text messages), mounted speakers and sirens, access locks, remote sensing satellite imagery, a border movement control system, information linkage devices, video cameras in strategic places and CCTV will help promote an environment that is safe from crime and terrorism. The eradication of arms and ammunition dealings that result in illicit arms falling into the hands of civilians is another measure to prevent terrorism in society. For the effective functioning of this measure, it is suggested that the community police be mostly mandated with the responsibility of monitoring these devices so that they can alert the security operatives within their jurisdiction for rapid response in case of any emergency or impending crime-related challenges.

Finally, the study suggests a review of Nigeria's Constitution and the Bill of Rights, as well as the institutionalization of strict regulations that compel the federal government to monitor and evaluate state governments in order for some of the above recommendations to materialize and produce more effective and desired results that will give the country a facelift from all sorts of ethno-religious, political and socio-economic problems which have, on frequent occasions, rekindled and fuelled the flames of terrorism in Nigeria.

\section{Acknowledgement}

This certifies that neither the article nor a version of it has been published, nor made publicly available online, nor is being considered for publication elsewhere, nor will be submitted for consideration for publication while the manuscript is under review by the JOURNAL.

\section{Author's Contributions}

Sogo Angel Olofinbiyi: Pioneer of the idea $(\mathrm{PhD}$ Project).

Jean Steyn: Supervisor of the project.

\section{Ethics}

Full confidentiality of all information and the anonymity of participants were maintained. Participants were informed of any potential limitations to their confidentiality of any information supplied. Procedures were put in place to protect the confidentiality of the information and the anonymity of the participants in all the research materials. The researcher made arrangements to provide adequate information about the research in all publications and to permit the methods and findings of the research to be properly assessed by his peers, colleagues and the public. The limits pertaining to reliability, accessibility and applicability were made clear.

\section{References}

Adesoji, A., 2010. Boko Haram uprising and islamic revivalism in Nigeria. Afr. Spectrum, 45: 95-108.

Adibe, J., 2012. Boko Haram: Symptom of crisis in our nation building project.

Agbiboa, D.E., 2013. The ongoing campaign of terror in Nigeria: Boko Haram versus the state. Int. J. Security Develop., 2: 1-18. DOI: 10.5334/sta.cl

Al Jazeera, 2016. Nigeria: Boko Haram 'releases 21 Chibok Girls'," Al Jazeera. 
Awojobi, O. N., 2014. The socio-economic implications of Boko Haram insurgency in the north-east of Nigeria. Int. J. Innovat. Sci. Res., 11: 144-150.

Bannon, L. and P. Collier, 2003. Natural Resources and Violent Conflict: Options and Actions. 1st Edn., World Bank Publications, Washington, DC, ISBN-10: 0821355031, pp: 409.

Bintube, M., 2015. Boko Haram phenomenon: Genesis and development in north-eastern region of Nigeria. Int. J. Sociol. Anthropol., 1: 1-2.

Blaxter, L., C. Hughes and M. Tight, 1997. How to Research. 1st Edn.,Redwood Books, London.

Bryman, A., 2012. Social Research Methods. 4th Edn., Oxford University Press, Oxford, ISBN-10: 0199588058, pp: 766.

Collier, P. and A. Hoeffler, 2004. Greed and grievance in civil war. Oxford Eco. Papers, 56: 563-595. DOI: $10.1093 /$ oep/gpf064

Cook, D., 2011. Boko Haram: A prognosis. Research Paper of James A. Baker, Institute for Public Policy, Rice University, USA.

Cunningham, K.J., 2003. Cross-regional trends in female terrorism. Studies Conflict Terrorism, 26: 171-195. DOI: $10.1080 / 10576100390211419$

Dollard, J., D. Leonard, N. Miller, O.H. Mowrer and S. Robert, 1939. Frustration and Aggression. 1st Edn., Yale University Press, New Haven, pp: 213.

Eneanya, A.N., 2015. Terrorism and global domestic insurgency nexus: A case of Boko Haram insurgency in Nigeria. J. Public Manage. Soc. Policy, 21: 78-94.

Faleti, A.S., 2006. Theories of Social Conflict. In: Introduction to Peace and Conflict Studies in West Africa: A Reader, Best, G.S. (Ed.), Spectrum Books, Ibadan, ISBN-10: 9977925402.

Gurr, T.R., 1970. Why Men Rebel. 1st Edn., Princeton University Press, Princeton, ISBN-10: 069107528X, pp: 421.

Gurr, T.R., 2000. Peoples Versus States: Minorities at Risk in the New Century. 1st Edn., United States Institute of Peace Press, Washington, D.C., ISBN-10: 1929223021, pp: 399.

Hagan, F., 2006. Research Methods in Criminal Justice and Criminology. 7th Edn., Allyn and Bacon, Boston, MA, ISBN-10: 0205447392, pp: 533.

Idahosa, O., 2015. Boko Haram and the Nigerian state: A different perspective. J. Culture, Polit. Innovat., 3: 1-28. DOI: $10.12893 /$ gjcpi.2015.3.5

Krippendorff, K., 1980. Content Analysis. 1st Edn.., SAGE, Beverly Hills, California.

Kwaja, C.A., 2009. Strategies for rebuilding state capacity to manage ethnic and religious conflict in Nigeria. J. Pan Afr. Studies, 3: 105-115.
Maiangwa, B., U.O. Uzodike, A. Whetho and H. Onapajo, 2016. Baptism by fire: Boko Haram and the reign of terror in Nigeria. Afr. Today, 59: 41-57. DOI: 10.2979/africatoday.59.2.41

Mason, J., 2002. Qualitative Researching. 2nd Edn., SAGE, London, ISBN-10: 0761974288, pp: 224.

Mustapha, A.R., 2012. Boko Haram: Killing in God's name. Mail and Guardian.

Ninalowo, A., 2011. On the Crisis of Underdevelopment. 1 st Edn., First Academic Publishers, Lagos.

Njoku, E.T., 2011. Globalization and terrorism in Nigeria. Foreign Policy J.

Olagunju, L.O., 2012. Boko Haram will destroy Jonathan's administration. The Guardian.

Olofinbiyi, S.A., 2017. Peaceful negotiations: Implications for the release of twenty-one Chibok girls from Boko Haram's captivity. Kujenga Amani: African Peacebuilding Network of the Social Science Research Council (APNSSRC).

Omede, A.J, 2011. Nigeria: Analysing the security challenges of the Goodluck Jonathan administration. Canadian Soc. Sci., 7: 90-102. DOI: $10.3968 /$ J.css. 1923669720110705.220

Oyefara, J.L., 2011. Socio-cultural context of adolescent fertility in Yoruba society: Insights from Osun State, Nigeria. 1st Edn., Concept Publications, Lagos, Nigeria, ISBN-10: 9789788406846, pp: 315.

Patton, M.Q., 2002. Qualitative Research and Evaluation Methods. 3rd Edn., SAGE, Thousand Oaks, CA, ISBN-10: 0761919716, pp: 598.

Pham, P.J., 2012. Boko Haram's evolving threat news briefs. Africa Centre for Strategic Studies.

Ritchie, J. and J. Lewis, 2014. Qualitative Research Practice: A Guide for Social Science Students and Researchers. 1st Edn.,Bonhill, London.

Ritchie, J. and L. Spencer, 1994. Qualitative Data Analysis for Applied Policy Research. In: Analyzing Qualitative Data, Bryman, A. and R.G. Burgess (Eds.), Routledge, London, pp: 173-194.

Rotberg, R., 2002. The new nature of nation-state failure. Washington Quarterly, 25: 85-96.

Rotberg, R.I., 2003. State Failure and State Weakness in a Time of Terror. 1st Edn., Brookings Institution Press, Washington, D.C., ISBN-10: 9780815775737 , pp: 456.

Schwartz, S.J., C.S. Dunkel and A.S. Waterman, 2009. Terrorism: An identity theory perspective. Studies Conflict Terrorism, 32; 537-539. DOI: $10.1080 / 10576100902888453$

Weber, R.P., 1990. Basic Content Analysis. 2nd Edn., SAGE, London, ISBN-10: 0803938632, pp: 96.

Zartman, W.I., 1995. Collapsed States: The Disintegration and Restoration of Legitimate Authority. 1st Edn., Lynne Rienner Publishers, Germany, ISBN-10: 1555875602, pp: 303. 